\title{
The Synergy Between Several Bacteria Isolated from the Biodiversity of UB Forest Coffee Litter in Vitro
}

\author{
Gallyndra Fatkhu Dinata, Luqman Qurata Aini*, Abdul Latief Abadi \\ Department of Plant Pests and Diseases, Faculty of Agriculture, Brawijaya University, Malang 65145, East \\ Java, Indonesia.
}

${ }^{*}$ Corresponding author:

E-mail: lqaini19@gmail.com

\begin{abstract}
Exploration of bacteria from coffee litter in UB Forest has several new studies, which have the ability as a biocontrol agent. From previous research, it was known the potential of coffee litter bacteria as the single biological control against basal rot in shallots. This study aims to evaluate the ability of bacteria to synergize with other beneficial bacteria of coffee litter. The research consisted of the preparation of coffee litter bacteria isolates and synergy tests using the cross streak method. Based on the research results, not all bacteria can form a consortium. Bacteria that can synergize with each other are Pseudomonas sp., and Alcaligenes faecalis. Three bacteria that cannot be synergized with each other, are Bacillus mycoides, Clostridium sp. and Erwinia sp which produces clear zones up to more than $30 \mathrm{~mm}$. This is preliminary research before starting a bacterial consortium. With this research, it is expected to be a solution for biological control from a consortium of beneficial bacteria from exploration in UB Forest.
\end{abstract}

Keywords: Bacteria consortium, biological control, coffee litter bacteria, synergy test, UB forest

\section{Introduction}

UB Forest is an educational forest of Universitas Brawijaya which has an area of 554 hectares, located on the slopes of Mount Arjuno, Malang (BUA UB, 2017). Coffee plant litter in UB Forest is very abundant and has not been used properly so that it provides an opportunity to explore antagonistic bacteria for controlling plant diseases. One of the bacteria found in a litter is the Bacillus sp. Bacteria of the genus Bacillus sp. is one of the endophytic bacteria that are in plant tissue in a litter (Yulma et al., 2017).

The utilization of beneficial bacteria in the form of a single isolate shows good potential to be used as biological agents (Dinata et al, 2018). However, the use of single beneficial bacteria is still not effective in controlling the disease. Further efforts to utilize beneficial bacteria as biological agents need to be made, one of which is in the form of a consortium. The use of a bacterial consortium in controlling plant diseases is considered to have better results than the use of a single isolate. This is because the bacterial consortium consists of several bacteria that work together and provide useful compounds or metabolites to each other.

Several studies have shown success in using a consortium of bacteria in controlling plant diseases. However, not all bacteria can synergize in vitro so it still needs research. Research on the combination antagonist bacteria consortium from Bacillus sp. and P. fluorescens in laboratory, greenhouse, and field testing can control bacterial wilt disease by R. solanacearum in tomato plants. The use of a consortium of antagonistic bacteria also has benefits in increasing plant resistance and growth. Greenhouse research results on tomato seed treatment showed that the consortium of B. subtilis, P. aeruginosa, Klebsiella pneumoniae and Citrobacter youngae significantly increased seedling height, stem circumference, number of leaves, and leaf area of tomato plants

\section{How to cite:}

Dinata, G. F., Aini, L. Q., \& Abadi, A. L. (2021). The synergy between several bacteria isolated from the biodiversity of UB Forest coffee litter in vitro. ${ }^{\text {st }}$ Bioinformatics and Biodiversity Conference. NST Proceedings. pages 25-30. doi: 10.11594/ nstp.2021.0704 
(Oluwambe \& Kofoworola, 2016). This research is expected to be the right solution for controlling plant diseases.

The determination of the success of using a bacterial consortium is still being studied, one of which is testing the ability of bacteria to synergize with each other or not. The success of a bacterial consortium is also influenced by the existing substrate. In the research, a consortium of indigenous bacteria from salt-containing swamps showed a synergistic growth that depends on the complexity of the substrate. Bacteria can synergize with each other when lignocellulose is the only carbon source available so that it can reduce the resulting substrate complex. Bacteria will antagonize each other when glucose is the only source of carbon and in limited quantities, bacteria will seize the substrate, resulting in the dominance of antagonistic interactions (Deng \& Wang, 2016). This study aims to evaluate the ability of bacteria to synergize with other coffee litter antagonists. This research is a preliminary study for a bacterial consortium which will be used further as a potential for biological control of plant diseases.

\section{Material and Methods}

\section{Study area and materials}

The experiment was conducted at the Laboratory of Plant Disease in Brawijaya University and in Sonosari, Kebonagung Village, Malang from December 2019 - April 2020. Bacterial strains used in this study were Bacillus mycoides, Clostridium sp., Pseudomonas sp., Erwinia sp., and Pseudomonas sp., which were isolated from coffee litter in UB Forest.

\section{Preparation of coffee litter bacteria isolates}

Antagonistic coffee litter bacteria isolate from stocks were grown on Natrium Agar (NA) to verify their purity. All bacteria were incubated for 24 hours at room temperature.

\section{Synergy test between coffee litter bacteria}

The synergy test was carried out with a modified cross streak which refers to Gurunathan et al., (2014). Figure 1 is an illustration of the synergy test of indigenous bacteria UB Forest coffee litter. The tested bacterial isolates were grown in line with the center of the Petri dish. After one day of incubation, other bacterial isolates were inoculated on the same Petri dishes in the same horizontal position or opposite to the previously grown bacteria. Bacteria were incubated for 24 hours to observe the inhibitory effect. A single-antagonistic bacterial isolate control Petri dish was also prepared to compare the same growth patterns.

Assessment of bacterial synergy is seen from the results on the Petri dish, whether the indigenous bacteria of UB Forest coffee litter can grow in synergy with each other. The synergy test is assessed based on the presence of a clear zone or zone of inhibition. The presence of clear zones is evidence that some bacteria are antagonistic to each other, whereas the absence of clear zones is an indication of synergism.

The criteria for evaluating the synergy test for antagonistic bacteria according to Djaenuddin and Faesal (2015) are as follows:

1. There is no barrier distance or clear zone between bacterial colonies.

2. There is a barrier distance or clear zone $<20 \mathrm{~mm}$ between the bacterial colonies.

3 . There is a distance of obstacles or clear zones of $20-30 \mathrm{~mm}$.

4. There is a distance of obstacles $>30 \mathrm{~mm}$. 


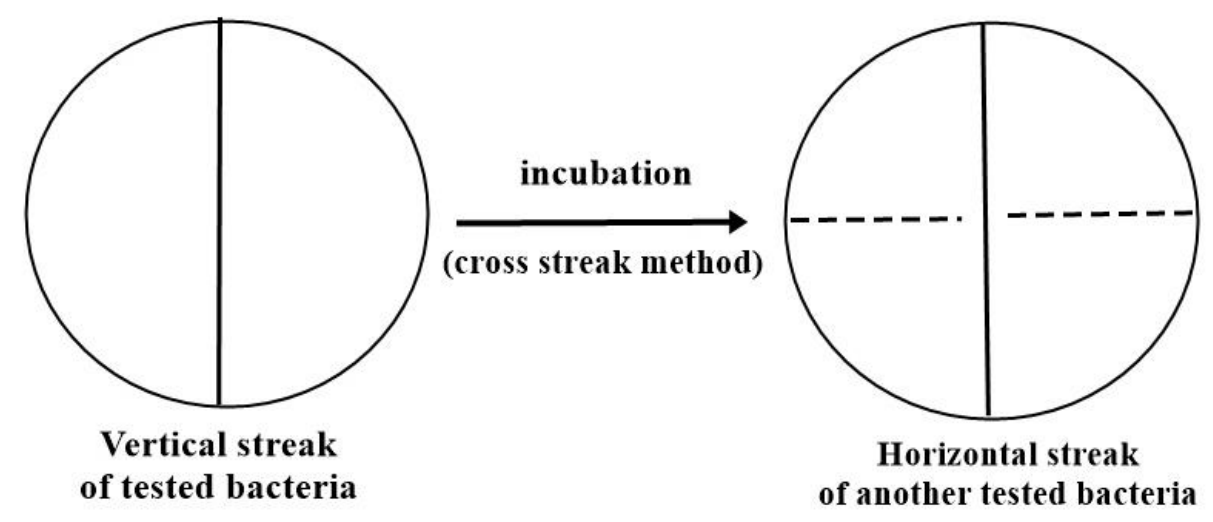

Figure 1. Cross streak method of antagonistic bacteria from coffee litter

\section{Results and Discussion}

\section{The synergy between coffee litter bacteria}

The synergy between different coffee litter bacteria lines shows variations, not all coffee litter bacteria are compatible with other coffee litter bacteria. The results of the coffee litter bacteria synergy test are shown in Table 1 and Fig. 2. The bacteria that can be formed by the consortium seen from the bacteria can be synergized with other bacteria which are indicated by the + symbol. Isolates of $B$. mycoides and Clostridium sp. not synergy with each other. Bacillus bacteria isolates can only synergize with Pseudomonas and E. faecalis, the same thing happened to Clostridium sp. However, in other genera, Erwinia sp can synergize with B. mycoides, Pseudomonas sp., and A. faecalis.

The bacteria that are not synergized can be seen from the test results of the two isolates, there is growth inhibition (clear zone) between the streaks of the two isolates, the bacteria produce a clear zone after being incubated for 24 hours at room temperature. Figure 2 shows that there is a growth inhibition (clear zone) between the meeting of B. mycoides and Clostridium sp. This meaning that these two species are not synergistic with each other, and cannot be used as a consortium of biological control antagonists. The measure of inhibition between Clostridium sp. with $B$. mycoides which is more than $30 \mathrm{~mm}$. The size of the inhibition produced differed between the bacteria tested. The variation and size of the clear zone produced by bacteria depend on the age of the bacterial culture, the number of bacteria inoculated, the composition of the media, the depth and conditions of the incubation.

Table 1. Result of synergy test of indigenous bacteria UB Forest coffee litter

\begin{tabular}{cccccc}
\hline Isolates & B. mycoides & Clostridium sp. & Pseudomonas sp. & Erwinia sp. & A. faecalis \\
\hline $\begin{array}{c}\text { B. mycoides } \\
\text { Clostridium sp. }\end{array}$ & -- & -- & + & - & + \\
$\begin{array}{c}\text { Pseudomonas sp. } \\
\text { Erwinia sp. }\end{array}$ & + & + & + & - & + \\
A. faecalis & + & - & + & + & + \\
\hline
\end{tabular}

Notes: (+) indicates the absence of inhibition, (-) indicates an inhibition of less than or equal to $20 \mathrm{~mm},(-)$ indicates an inhibition of more than $30 \mathrm{~mm}$. 
The synergy test evaluates the synergy of two coffee litter bacteria in the same nutrient utilization and space. With the presence of an inhibitory zone in the B. mycoides and Clostridium sp test that ranges from $30 \mathrm{~mm}$, it is suspected that the extracellular metabolite reactions produced by one or both of these antagonists can inhibit the growth of each other. The inhibition mechanism of this fellow antagonist can be explained in the feed-back inhibition process in continuous culture (Madigan et al., 1979 in Edy, 2011) where toxic compounds produced excessively by antagonistic bacteria in the media can inhibit their growth. Although in vitro incompatibility events between antagonistic bacteria of other species may occur, this condition does not occur in field application testing, because antagonism to pathogens is determined by many factors such as antibiotic and toxin production, induction of plant resistance, and competition.

Figure 1.

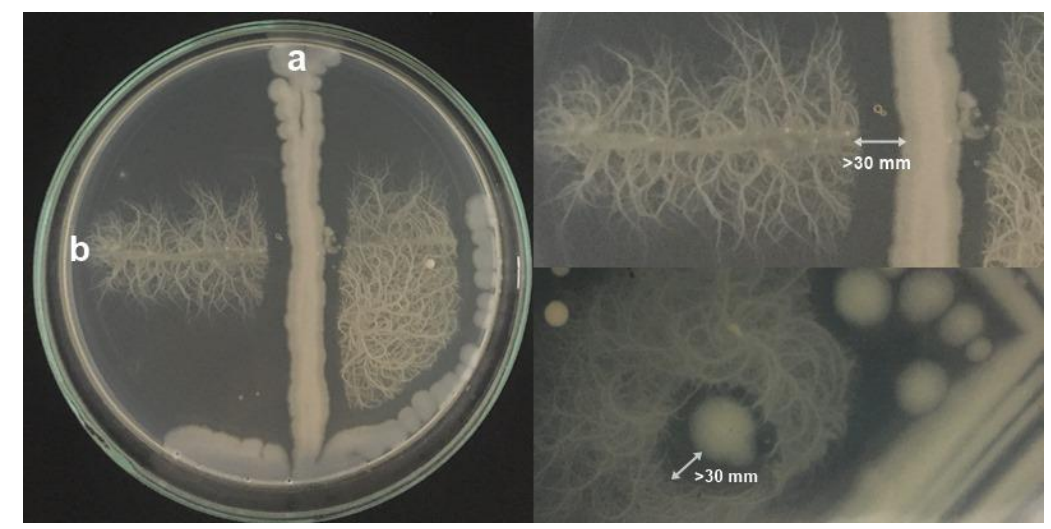

not synergize. a. Clostridium sp. b. B. mycoides. There is a clear zone $>30 \mathrm{~mm}$

Bacteria that do

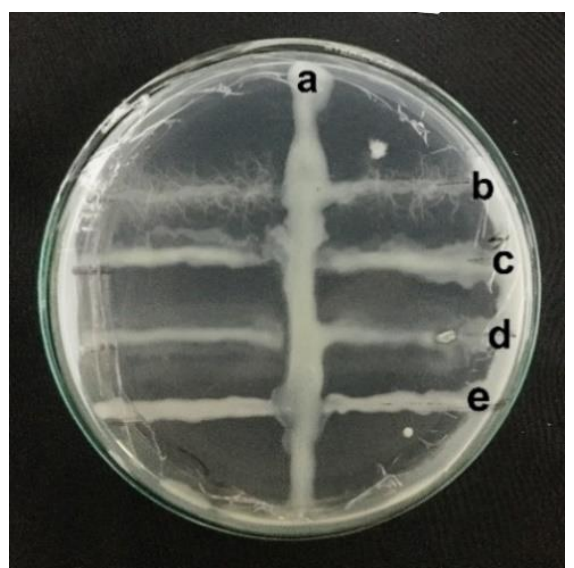

Figure 2. Bacteria synergizing with each other a. A. faecalis, b. B. mycoides, c. Erwinia sp., d: Pseudomonas sp. e: Clostridium sp.

\section{Discussion}

Two bacteria that are compatible with each other are Pseudomonas sp., and A. faecalis which can synergize with all coffee litter bacteria. These bacteria show synergy because there is no inhibition (clear zone) between the intersection points of the two isolates after being incubated 24 hours at room temperature so that the bacteria can be used as a consortium of antagonistic bacteria for biological control. Based on the results of the synergy test of A. faecalis and Pseudomonas sp. able to combine with all bacteria (Fig. 3). The ability of the two antagonistic bacteria to synergize with each other is thought that the antagonistic bacteria can grow by producing compounds that are mutually beneficial for each other's growth. This is supported by the statement of Deng \& Wang (2016), bacteria can synergize with each other when lignocellulose is the only carbon 
source available so that it can reduce the resulting substrate complex. Bacteria will antagonize each other when glucose is the only source of carbon and in limited quantities, bacteria will seize the substrate, resulting in the dominance of antagonistic interactions. Pseudomonas has several antibiotics against plant pathogens. Grinter et al (2012) reported that P. syringae PV tomato produce bacteriocin, namely syringacin. $A$. faecalis is a Gram-negative bacterial found in soil, water, and the environment. A. faecalis has potential as a biostimulant and bioprotectant. There are several studies related to $A$. faecalis as plant control. In certain subspecies studies such as $A$. faecalis subsp. phenolicus MB207 has a useful compound, namely fusaric acid which can inhibit the growth of pathogens (Basharat et al. 2018).

In this cross-streak method, the clear zone is detected against several sensitive bacteria. This can be caused by many factors, the distribution of cell loads, the composition of the cell walls, and the diffusion of the antagonist compound into the medium (Gurunathan et al., 2014). Also, the ability of bacteria to synergize is caused by several types of bacteria tested, the distribution of charge, the content of the bacterial cell wall, and the diffusion of the antagonistic bacterial molecules into the growing medium (Laukova \& Marekova, 1993). In testing the synergy with the modified scratch method, it can be seen that the ability of coffee litter bacteria to synergize or not. This method can also evaluate the inhibitory activity of one of the strains of bacteria to produce antagonistic properties against several other bacteria that are more sensitive (Gurunathan et al., 2014).

Based on the synergy between the coffee litter antagonists, at least seven consortium combinations of coffee litter bacteria were obtained, consisting of two coffee litter antagonist bacteria that can be used as consortium cultures in vitro. The consortium combination can also be used with more than two bacteria seen from the synergy test results. Many interactions occur between different types of bacteria and often result in the in-plant promotion of plant growth and resistance. Consortium bacteria synergize through other bacteria to obtain energy to survive. Bacteria utilize coenzymes produced by other microbes (Septiningrum \& Hardiani, 2016). Bacteria from different genera can relate to each other and survive through metabolite interactions. Between microorganisms can use a compound and its metabolites as a carbon source, resulting in synergism during the transformation (Bouchez et al., 1999). Also, the performance of microbial enzymes can complement each other, so that microbes can survive by utilizing nutritional sources available in nature (Okoh, 2006). The good of bacterial consortium is also influenced by the existing substrate. The research of a consortium of indigenous bacteria from salt-containing swamps showed a synergistic growth that depends on the complexity of the substrate. Bacteria can synergize with each other when lignocellulose is the only carbon source available so that it can reduce the resulting substrate complex. Bacteria will antagonize each other when glucose is the only source of carbon and in limited quantities, they will seize the substrate, resulting in the dominance of antagonistic interactions (Deng \& Wang, 2016). The success of using the consortium is also influenced by where the bacteria are isolated. The use of a microbial consortium from a certain place of origin will provide a higher level of pollutant mineralization (Vinas et al., 2002). This is presumably due to the ability of the bacterial consortium to have strong properties in maintaining their original ability to cooperate. This also applies to bacterial strains that do not have biodegradability but have the potential to promote growth (Richard \& Vogel, 1999 in Zanaroli et al., 2010).

\section{Conclusion}

Not all antagonistic bacteria from UB Forest coffee litter can form a consortium. Only A. faecalis and Pseudomonas sp isolates, which can be combined with all bacterial isolates for synergy. It is necessary to test the consortium of bacterial isolates to see their effectiveness in controlling plant diseases and what compounds they produce 


\section{References}

Basharat, Z., Yasmin, A., He, T. \& Y. Tong. (2018). Genome sequencing and analysis of Alcaligenes faecalis subsp. phenolicus MB207. Sci Rep 8, 3616 (2018). https://doi.org/10.1038/s41598-018-21919-4.

Bouchez, M., Blanchet, D., Bardin, V., Haeseler, F., \& Vandecasteele, J.P. (1999). Efficiency of defined strains and of soil consortia in the biodegradation of polycyclic aromatic hydrocarbon (PAH) mixtures. Biodegradation, 10: 429-435. https://doi.org/10.1023/A:1008382030604

BUA UB. (2017). UB Forest, Badan Usaha Akademik UB. Available at http://bua.ub.ac.id/ubforest/

Deng, Y.J., \& Wang S.Y. (2016). Synergistic growth in bacteria depends on substrate complexity. Journal Microbiology, 54(1), 23-30. https://doi.org/10.1007/s12275-016-5461-9

Dinata, G.F., Aini, L.Q \& Kusuma R.R. (2018). Potensi bakteri dari serasah tanaman kopi di UB forest untuk mengendalikan penyakit busuk pangkal batang (Fusarium oxysporum f.sp. cepae) pada tanaman bawang merah. Sarjana thesis. Universitas Brawijaya.

Djaenuddin, N. \& Faesal. (2015). Uji kombinasi antara isolatisolat bakteri dan cendawan dekomposer in vitro. hlm 355- 361. Dalam: A. Muis, Syafruddin, Bahtiar, dan M. Aqil (eds). Prosiding Seminar Nasional Serealia. Maros: Pusat Penelitian dan Pengembangan Tanaman Pangan.

Edy, Nur. (2011). Biological control of banana blood disease using Pseudomonas fluorescent and Bacillus spp. Journal Agroland, 18 (1), 29 - 35. https://dx.doi.org/10.22487/J.24077607.2011.v18.i1.2502

Grinter, R., Roszak, A.W., Cogdell, R.J., Milner, J.J., \& Walker, D. (2012). The crystal structure of the lipid II-degrading bacteriocin syringacin M suggests unexpected evolutionary relationships between colicin M-like bacteriocins. Journal of Biologival Chemistry, 287(46): 38876-38888. https://doi:10.1074/ibc.M112.400150

Gurunathan, S., Umashankar, V., Murugesan, S., \& Dhamotharan, R. (2014). 16s rDNA based molecular identification of Bacteriocin-like inhibitory substance (BLIS / BIS) producing indigenous phytopathogenic bacteria isolated from various diseased plant materials. International Journal of Current Science, 11, 105-119.

Laukova, A, Marekova, M. (1993). Antimicrobial spectrum of bacteriocin-like substances produced by Staphylococci. Folia Microbiologica, 38, 74-76. https://doi.org/10.1007/BF02814554

Madigan, M.T., J.M. Martinko, and J. Parker.1997. Biology of Microorganisms. Prentice Hall International, Inc

Okoh, A. (2006). Biodegradation alternative in the cleanup of petroleum. Biotechnology and Molecular Biology, 1 (6), 38-50.

Oluwambe, T.M., \& Kofoworola, A.A. (2016). Comparison of single culture and the consortium of growth-promoting rhizobacteria from three tomato varieties. Advances in Plants \& Agriculture Research, 5(1), 448-455. https://doi.org/10.15406/apar.2016.05.00167

Septiningrum, K., \& Hardiani, H. (2016). Application of microbial consortium to remediate lead contaminated soil from the waste of the paper industry drinking process. Journal of Cellulose, 1 (02), 89-101. http://dx.doi.org/10.25269/jsel.v1i02.24

Richard, J.Y., \& Vogel, T.M. (1999). Characterization of a soilbacterial consortium capable of degrading diesel fuel. International Biodeterioration \& Biodegradation. 44, 93. https://doi.org/10.1016/S0964-8305(99)00062-1

Vinas, M., Grifoll, M., Sabaté., J., \& Solanas. A.M. (2002). Biodegradation of a crude oil by three microbial consortia of different origins and metabolic capabilities. Journal of Industrial Microbiology \& Biotechnology, $28 \quad$ (5), 252-260. https://doi.org/10.1038/si/jim/7000236

Yulma Y, B Ihsan, S Sunarti, E Malasari, N Wahyuni \& M Mursyban (2017). Identification of Bacteria in Decomposed Mangrove Leaf Litter in the Mangrove and Bekantan Conservation Areas (KKMB) of Tarakan City. Journal of Tropical Biodiversity and Biotechnology, 2(1), 28-23. https://doi.org/10.22146/jtbb.27173

Zanaroli, G., Di Toro, S., Todaro, D., Varese, G.C., Bertolotto, A., \& Fava, F.A. 2010. Characterization of two diesel fuel degrading microbial consortia enriched from a non-acclimated, complex source of microorganisms. Microbial Cell Factories., 9, 1-13. https://doi.org/10.1186/1475-2859-9-10 